\title{
Body-Kinaesthetic Program for Toddlers During the Covid-19 Pandemic
}

\author{
Indriyana Wahyuni ${ }^{1, *}$, Euis Kurniati ${ }^{2}$ \\ ${ }^{1,2}$ Universitas Pendidikan Indonesia \\ *Corresponding author Email: indri678allen@gmail.com
}

\begin{abstract}
Covid-19 pandemics that occur throughout the world have issued various policies including school from home. The process of playing and learning in this situation will certainly have an impact on various aspects of a child's development, including his physical motor development. At toddler age children need a lot of movement, running, jumping and more body-kinaesthetic intelligence exploration, but these pandemic conditions make exploration very limited. In this case, the teacher and parents need to find and develop programs that can meet the needs of toddler-age children to move. Based on this, this article aims to find out how to provide appropriate and sustainable stimulus in developing bodilykinaesthetic intelligence that can be implemented by teachers and parents during school from home. This research will lead to ideas of gross motor activities that are right on target for toddler age children by packaging their activities in the form of play. The method used in this research is library research and development, in which the researcher conducts a study of literature studies related to motor development of toddler-age children to then develop their body-kinaesthetic development programs. The results of this study are expected to be a reference for teachers and parents in stimulating toddler age children while implementing the school from home program.
\end{abstract}

Keywords: School from home, bodily-kinaesthetic intelligence, gross motor.

\section{INTRODUCTION}

Developing gross motor skills at the age of toddler is very important. At this age, children experience an exploratory phase with their limbs. They just realized that they can move their hands and feet, explore with the five senses, and practice the ability to make sounds. Along with this developing age, we as parents must be able to guide these children to develop abilities based on ageappropriate developmental aspects [1].

The toddler phase is a phase with 12-36 months of age, where children are too old to be called babies and too young are called children [2]. According to the Child Development Achievement Level Standards in the 1236-month age group, the physical-motor scope such as walk alone without falling, jump on the spot, go up and down stairs or higher places with assistance, walk back a few steps, pull and push light objects (example small chairs or boxes). While the children at home give some practice to play with a ball by throwing or kicking it. This assertion is based on the fact that in mobilization pedal skills (e.g., kicking a ball) both the right and left legs play an active role in task execution, with one leg producing the desired motion while the other leg stabilizes body balance [3]. In another context, when stabilization is the main component of the action (e.g., keeping static balance on one foot), the supporting leg plays the main role while the contralateral leg remains motionless or is used to produce only auxiliary movements [4]. As their balancing is fine in this stage, we may continue to give some practices such as stand on one foot or squat.

From several other aspects of development, the physical-motor point development points are the most numerous. This means that our focus is on developing bodily-kinaesthetic abilities at this age. Some important things that must be considered in developing the abilities of a toddler [4], namely: physical growth in toddlers is slower than in infants, but only at a predictable rate. They allow time for the exploration of the situation, here gross and fine motor development develops more rapidly, anger is a form of expression when they try and try to be independent, behaviour and emotions greatly influence all interactions [5]. Toddlers make important transitions from thinking to preoperational thinking; form a stable and reasonable concept, and language development occurs through the introduction of symbols (preoperational stage).

By knowing every need at this age, we, parents and teachers can determine the right activities and games that 
toddlers are able to do instead of putting pressure on activities that are not yet time for them to do. Here the author wants to provide ideas and strategies for deciding motoric activities that suit the needs of toddlers by paying attention to every aspect of development required and the level of age maturity, as well as providing knowledge for parents in providing assistance during bodilykinaesthetic lessons. Sometimes parents or teachers put this aside, they focus only on their activities but forget what their real purpose is to provide these activities, what goals must be achieved, to what extent a toddler can stimulate himself in every given bodily-kinaesthetic activity. For example: when toddlers do an activity, they will involve emotion and anger, because there is a sense of frustration that occurs if they can't do something, if we provide running activities on one leg, even though at this stage they can only stand on one leg, what is that? Will it occur? For that, every adult must understand the needs needed by this age and position himself more towards his role.

\section{LITERATURE REVIEW}

The child's bodily-kinaesthetic abilities will be seen in how active the child is in playing. As we know, the essence of early childhood is play. So that in developing and stimulating its developments is by combining motoric movements with play. When they play, they use all the senses. Human senses undoubtedly influence experience because people perceive and understand the world around them through the sensory system. As well as children, this will be very helpful in terms of coordination between eyes and hands, eyes with feet, body balance and the ability to control strength will also accompany, for example when running, they will explore running speed, "Am I able to run fast or slow? Or what happens when I run fast or slow?" Our task as parents and educators here is to train their running skills, how the child maintains his body balance while running, how the child moves his feet while running, does he tiptoe or not follow the predetermined direction or does the child not run in a way that is right?

In general, there are three stages of the development of motor skills of children at this age, namely the stage of cognitive, stage of associative, and stage of autonomous. Stage of Cognitive. At this stage, the child tries to understand his motor skills and identifies the movements that will be used when he is required to make a movement. At this time, the child will remember previous events that have been done (if they have) or the child will try to imitate the movement being exemplified in front of him.

Stage of Associative. At this stage, children will learn about doing the movements that have been taught before without making repeated mistakes. Here the child will motivate himself to try to make the right movements and find out how best to carry out the requested movement.
In this stage, the movement shown by the child is a response in which when the child makes a movement, they will be able to avoid mistakes. The movements in this stage have started to be directed automatically and clearly recorded in their memories. Stage of Autonomous. In this stage, children have their own ability to determine all decisions on their morality and behaviour. The morality that is reflected in him has been based on his own experiences. Here, they get to use their surroundings, things and people around.

The three stages above can easily be carried out when the teacher and child come face to face. Direction and corrections can be carried out in accordance with the wishes and achievement of the expected development targets. But in the current pandemic when children do school from home, how do we develop children's bodilykinaesthetic abilities virtually, whether learning and teaching activities can be done effectively and efficiently, how can a teacher correct children's movement mistakes, whether people parents at home are able to provide the expected example to the child, and whether the messages and directions given by the teacher can be well received by the child and parents from home. To do learning from home during pandemic, the teacher must pay attention to the child's character, both emotionally, cognitively, language, and psychologically [20].

Piaget, in his book "Play, Dreams, and Imitation in Childhood", 1951, revealed that there are three types of games, namely training games, symbolic games, and games with rules. For toddlers, the game can be started by doing an exercise game using motoric sensory. According to Armstrong in [5], kinaesthetic intelligence is a person's skill in using limbs to express ideas or ideas. Gardner in [5] states that kinaesthetic intelligence is a person's ability to use their body to solve problems.

\section{METHOD}

The writing method used in this article is library research. In using the library research, researchers collect data through journals related to writing, read several reference books and conduct interviews with parents and preschool and kindergarten teachers.

The purpose of this study is to provide the best solution for parents and teachers in finding strategies for developing the bodily-kinaesthetic abilities of toddlers while doing school from home.

\section{RESULTS AND DISCUSSION}

Based on literature study, the researcher can conclude that there are several obstacles when carrying out bodily-kinaesthetic activities during school from home for toddlers, including:

1. Too many distractions from home, 
2. Children lacks focus, cannot sit for too long, and do not stare at the camera calmly,

3. The signal is less stable. Limited internet quota

4. Children are more interested in their own toys and have a desire to show their toys to friends in front of the camera,

5. Instructions and examples of teachers are not well received from home, because the sound is not clear, the signal is intermittent, and the movements exemplified are also interrupted,

6. Parents do not accompany children from the beginning to the end of the activity,

7. Children get bored too quickly,

8. Activities are less attractive to children,

9. Limited items that must be provided from the house,

10. Lack of motivation from parents

Some of the strategies undertaken by the teacher to overcome the above obstacles include:

1. Give suggestions to parents to provide assistance from the beginning of the activity to the end

2. Looking at the home situation of each child, for example how big the room is, how safe is it, making notes on what objects the children have, especially those related to physical activity, for example balls, ropes, chairs and so on.

3. Make activities that are fun for toddlers, for example children like to play ball, so make activities using balls

4. Provide activities that move a lot, not only staring at the camera, for example running or playing hide and seek

5. Get in the habit of warming up by playing before entering core lessons

6. Use music and songs, because children at this age really like dancing and singing movements

7. Always encourage and motivate children by involving and calling their names in every activity

8. Provide opportunities for children to try these activities one by one

9. Creating a challenging and exciting game.

10. Able to modify activities, read situations when children feel bored and replace these activities quickly.

Why do we still need to stimulate toddler's bodilykinaesthetic respond during pandemic?
1. A toddler needs to be able to move and complete tasks independently

2. To be able to explore the world around them

3. To give them confidence and independence, which promotes skills such as cognitive, speech/language, social emotional, and sensory development

4. To meet developmental milestones

5. To help preventing early motor delays.

Toddler-age children still really need encouragement and motivation in carrying out activities. Kindergarten practitioners' experience of promoting children's involvement in and enjoyment of physically active play [6]. Does the contagion of physical energy affect physically active play?

During physical play, it is important for children to understand the meaning of the activities and the conditions under which they are invited to play; the contributions of others may be significant. Affective dialogue based on awareness, rhythm, and movement will continue to play a major role in communication throughout life, with increasing variety and complexity [7]. Creating relationships that children can recognize and experience their contribution as an essential element of an ongoing relationship is essential for development, and allows children to live new adventures and life experiences [7]. If children are given different experiences in each activity, their motor will develop very quickly. Body balance and coordination will continue growing, example when they play jumping rope. Jumping rope is a widely-used and non-specific practical method for the development of athletic conditioning, balance and coordination in several disciplines [8]. Constantly communicating during play will improve his language skills. Likewise, if we invite children to play with physical activity continuously, this activity will increase their motor sensory.

During this school from home, the role of parents is very important. In addition to being a teacher, the role of multiple parents is also a motivator, guide, supervisor, and facilitator. Some parents may still find it difficult to accompany their children while studying at home. Especially at these age children are often "moody", for example there are conditions that must be done by them first before studying. Like having to play first or sometimes parents force themselves to give tantalizing promises to children, here parents have done their role as motivators. Here we can capture that the real essence is to play, so be playful parents and become a motivator for children during mentoring for this moment. Parents must understand their roles, between father and mother sharing tasks. Parents need to add insight into knowledge related to effective ways of educating children and children's learning materials, creating a pleasant home atmosphere 
and carrying out activities with children by providing alternative activities so that children don't get bored quickly.

Here are some tips that can be applied for parents during school from home:

1. Be a playful parent.

2. Able to manage time (time management) properly. Set a schedule of mentoring with work.

3. Read carefully the lesson plans provided by the teacher.

4. Prepare media and equipment at least 3 days before the online class.

5. Trying to exemplify the movements through the teacher's video before modelling them to the children.

6. Being a partner of children not being a teacher; invite instead of ordering, meaning that bodykinaesthetic activities will be more fun when done together, and trying to understand the desires of children and limited communication skills at this age, use children's language, language that children understand.

7. Always encourage children. Give motivational words and rewards if they can make the move correctly.

8. Become a good role model. Make this moment a bonding moment with your child.

9. Be patient and don't give up with situations, for example be tolerant of situations when the signal is less stable or the image is less clear, and so on.

10. Always communicate with the teacher.

The role of parents in stimulating gross motor skills through bodily-kinaesthetic activities from the home. Stimulating children, parents must provide an understanding of what the child sees, hears, feels, feels, and treats him with great affection [1]. The development of the basic abilities of children correlates with growth. A child has very sharp eyesight, but does not yet have understanding, opinion or criticism. Therefore, parents are required to know and understand what should be done at all times. During school from home, parents are expected to be able to understand the need for gross motor stimulation that is appropriate for toddlers. Some of the results seen during the pandemic, the gross motor skills of children while at home have decreased.

The stimulation does not work properly because of these factors:

1. Parents need to understand what gross motoric mean. Gross motor skills are the ability to move the body using large muscles, most or all of the gross motor body parts are needed so that children can sit, kick, run, go up and down stairs and so on [9]. The development of children's gross motor skills takes precedence over fine motor skills, for example, children will handle large objects first than small ones. Because children are not able to control the movement of their fingers for their fine motor skills, such as cutting and drawing. We argue that gross motor movement is an ability that requires coordination of most parts of the child's body [10]. Gross motor development of children includes the use of gross muscles. Gross motor movements involve the activity of large muscles such as hand muscles, leg muscles and the entire body of the child.

2. Know the types of gross motor skills. Motoric abilities includes reaction speed, balance, agility, and coordination [11]. The Relationship between Mother Stimulation and Motor Development in Children aged 2-3 years, there are 2 types of skills used in developing children's gross motor, namely locomotors, non-locomotors, and manipulative skills [12]. Locomotors is a skill used by children to move their body from one place to another. For example, running, sliding, climbing, galloping (running like a horse), etc. Non-locomotors is a skill that is used by children to do activities on the spot. Such as swinging hands to left and right, bending legs, doing muscle stretching, and so on [13]. Manipulative is a skill that children create when they master an object [14], [15]. For example, when a child is given a ball, the child will use a lot of hands and feet, so when they play the ball the child will coordinate the body balance with his hands and feet, such as kicking a ball, bouncing, throwing the ball into a basket, etc.

3. Do exercise continually. It is hoped that the activities that have been exemplified by the teacher and can be repeated at home [16], [17] Parents can modify activity. Create an activity in which two or three activities are carried out. For example, passing obstacles, the child will reach the final goal by having to do three things that have been determined [18], [19]. Some examples of body-kinaesthetic activities, that can be done at home includes pillow fight, jump rope, play obstacle course, hide and seek, mouse and cat, search for treasure, sing new songs by dancing, save trapped animals (dolls), become a secret agent on missions, number stepping stones, hear and run to letter sound, and so on. 


\section{CONCLUSION}

Assisting in learning at home during a pandemic is a challenge, not only for schools but also for parents, especially in providing assistance for motor activities. One of the challenges is providing lessons and activities that are appropriate for the child's development. It is hoped that as long as children learn from home, their abilities and skills will increase or walk according to their growth.

Providing lessons and activities that are appropriate to develop motor skills through bodily-kinaesthetic activities for toddler are important. Pandemic doesn't stop them from growing, as long as children have a willingness to learn and parents together with teachers, hands in hands guide them to improve all the needs. A teacher is required to provide fun activities, easy and active which focus on developing body balance and hand and foot coordination of toddlers. Meanwhile, parents become an extension of the teacher's hands to give direct examples in front of children when children need them and observe an activity which they will then imitate. This motor activity can be modified by incorporating other activities, for example learning to count while running and collecting objects and counting the numbers, and so on.

Recommendation for teachers to parents is to be able to make guidelines on how to practice motoric movements that can do at home written in syllabus and manual modules. Then invite the teaching staff together to create games that are fun, up to date, and creative in an effort to develop the abilities of toddler age children more optimally.

\section{REFERENCES}

[1] Lilawati A. Peran orang tua dalam mendukung kegiatan pembelajaran di rumah pada masa pandemi. Jurnal Obsesi: Jurnal Pendidikan Anak Usia Dini. 2020;5(1):549-58.

[2] Mitayani Y, Nursetiawati S. Hubungan stimulasi ibu dengan perkembangan motorik pada anak usia 2-3 tahun (toddler). JKKP (Jurnal Kesejahteraan Keluarga dan Pendidikan). 2015;2(1):59-67. Available from: https://doi.org/10. 21009/JKKP.021.09.

[3] Gustiana AD. Pengaruh permainan modifikasi terhadap kemampuan motorik kasar dan kognitif anak usia dini (studi kuasi eksperimen pada kelompok b TK Kartika dan TK Lab. UPI). pedagogik-pendas. 2014;2(2):279-89.

[4] Lehner DC. Toddler developmental delays after extensive hospitalization: Primary care practitioner guidelines. Pediatric nursing. 2015;41(5): 236-47.

[5] Anggreni MA. Metode bermain untuk mengembangkan kecerdasan anak usia dini. Buana
Pendidikan: Jurnal Fakultas Keguruan dan Ilmu Pendidikan. 2014;10(18):1-12. Available from: https://doi.org/10.36456/bp.vol10.no18.a1283.

[6] Bjørgen K, Svendsen B. Kindergarten practitioners' experience of promoting children's involvement in and enjoyment of physically active play: Does the contagion of physical energy affect physically active play? Contemporary Issues in Early Childhood. 2015;16(3):257-71. Available from: DOI: $10.1177 / 1463949115600025$.

[7] Fitzpatrick C, Pagani LS. Toddler working memory skills predict kindergarten school readiness. Intelligence. 2012;40(2):205-12. Available from: DOI: $10.1016 /$ j.intell.2011.11.007.

[8] Trecroci A, Cavaggioni L, Caccia R, Alberti G. Jump rope training: Balance and motor coordination in preadolescent soccer players. Journal of sports science \& medicine. 2015;14(4):792.

[9] Gabbard SH. Examining the stabilising characteristics of footedness. Laterality: Asymmetries of Body, Brain and Cognition. 1997;2(1):17-26.

[10] Teixeira LA, de Oliveira DL, Romano RG, Correa SC. Leg preference and interlateral asymmetry of balance stability in soccer players. Research quarterly for exercise and sport. 2011;82(1):21-7.

[11] Pratiwi AD, Irdawati I. Hubungan Pengetahuan Ibu Tentang Bermain Dengan Perkembangan Motorik Kasar Pada Anak Toddler. Jurnal Berita Ilmu Keperawatan. 2017;10(1):36-43.

[12] Fediani Y, Santoso B, Kadir MR, Dewi MR. The recommended aerobic gymnastics has better effects on improving cognitive and motoric ability in children. Bioscientia Medicina: Journal of Biomedicine and Translational Research. 2018;2(3):25-34.

[13] Chairilsyah D. Web-Based application to measure motoric development of early childhood. Jurnal Pendidikan Usia Dini. 2019;13(1):1-4. Available at https://doi.org/10. 21009/10.21009/JPUD.131.01.

[14] Grønbæk K, Iversen OS, Kortbek KJ, Nielsen KR, Aagaard L. Interactive floor support for kinesthetic interaction in children learning environments. InIFIP Conference on Human-Computer Interaction. 2007:4663:361-375. Springer, Berlin, Heidelberg. Available from: https://link.springer. com/chapter/10.1007/978-3-540-74800-7_32.

[15] Furnham A. Parents' estimates of their own and their children's multiple intelligences. British Journal of Developmental Psychology. 2000;18(4):583-94. Available from: https://doi.org/10.1348/ 026151000165869 .

[16]Li KY, Su WJ, Fu HW, Pickett KA. Kinesthetic deficit in children with developmental coordination 
disorder. Research in developmental disabilities. 2015;38:125-33. Available from: https://doi.org/10. 1016/j.ridd.2014.12.013.

[17] Orlick T, McCaffrey N. Mental training with children for sport and life. The sport psychologist. 1991;5(4):322-34. Available from: https://doi. org/10.1123/ tsp.5.4.322.

[18] Fitzpatrick P, Flynn N. Dynamic (kinesthetic) touch perception in preschool children. Ecological Psychology. 2010;22(2):89-118. Available from: https://doi.org/10.1080/10407411003719983.

[19] Tapia MI, Och deAlda JAG, Jeong JS, et al. Teaching and classroom communication with children in the COVID-19 pandemic. Epub ahead of print 11 November 2020:1-28. Available from: DOI: 10.35542/osf.io/8sa27. 